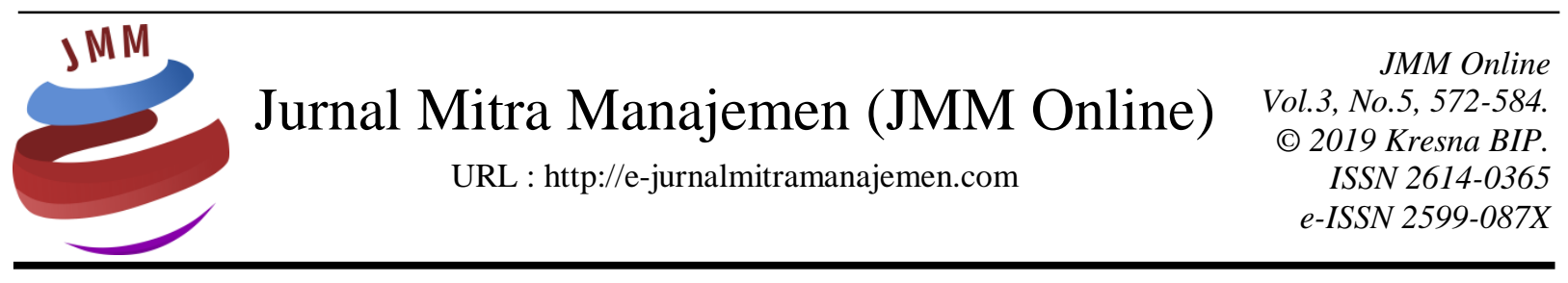

\title{
KEPUASAN KERJA PEGAWAI BADAN PERENCANAAN PEMBANGUNAN DAERAH (BAPPEDA) KABUPATEN BOJONEGORO DITINJAU DARI ASPEK KOMUNIKASI, MOTIVASI DAN LINGKUNGAN KERJA
}

\author{
Yuseriza Anugerah Leksana ${ }^{1)}$, Mei Indrawati ${ }^{2)}$, Hidayat ${ }^{3)}$ \\ Badan Perencanaan Pembangunan Daerah Kabupaten Bojonegoro
}

INFORMASI ARTIKEL

Dikirim : 10 Mei 2019

Revisi pertama : 17 Mei 2019

Diterima : 22 Mei 2019

Tersedia online : 31 Mei 2019

Kata Kunci : Kepuasan Kerja, Komunikasi, Motivasi, Lingkungan Kerja

Email : yuseriza@gmail.com

\section{ABSTRAK}

Tujuan penelitian ini adalah untuk mendeskripsikan komunikasi, motivasi dan lingkungan kerja serta kepuasan kerja pegawai di Bappeda Kabupaten Bojonegoro; mengetahui dan menganalisis pengaruh komunikasi, motivasi dan lingkungan kerja secara simultan terhadap kepuasan kerja pegawai di Bappeda Kabupaten Bojonegoro; serta mengetahui dan menganalisis pengaruh komunikasi, motivasi dan lingkungan kerja secara parsial terhadap kepuasan kerja pegawai di Bappeda Kabupaten Bojonegoro.

Populasi dalam penelitian ini adalah Pegawai Badan Perencanaan Pembangunan Daerah Kabupaten Bojonegoro sebanyak 39 orang dengan jumlah sampel 38 orang. Teknik pengambilan sampel yang digunakan dalam penelitian diambil secara total atau menggunakan metode sensus sampling. Teknik analisis data menggunakan teknik uji statistik melalui alat bantu program SPSS. Untuk mengetahui pengaruh antar variabel digunakan analisis dengan teknik Regresi Linier Berganda.

Hasil penelitian menunjukkan bahwa kondisi komunikasi, motivasi, lingkungan kerja dan Kepuasan kerja di Bappeda Kabupaten Bojonegoro semuanya dalam kategori baik; secara simultan komunikasi, motivasi dan lingkungan kerja mempunyai pengaruh yang signifikan terhadap kepuasan kerja Pegawai Bappeda Kabupaten Bojonegoro. Secara parsial motivasi dan lingkungan kerja mempunyai pengaruh yang signifikan terhadap Kepuasan kerja Pegawai Bappeda Kabupaten Bojonegoro. 


\section{PENDAHULUAN \\ Latar Belakang}

Mengingat begitu pentingnya faktor sumber daya manusia dalam mencapai tujuan jangka panjang dan jangka pendek, maka dengan demikian semakin disadari bahwa dalam suatu organisasi manusia merupakan unsur yang terpenting sehingga pemeliharaan hubungan yang berkelanjutan dan serasi atas manusia mutlak diperlukan sehingga sudah selayaknya semua kebutuhan pegawai perlu mendapat perhatian. Tanpa manajemen sumber daya manusia yang handal, pengelolaan penggunaan dan pemanfaatan sumber-sumber lainnya menjadi tidak berdaya guna dan berhasil guna.

Kepuasan kerja pegawai menjadi permasalahan yang sangat penting bagi Badan Perencanaan Pembangunan Daerah Kabupaten Bojonegoro (Bappeda) Kabupaten Bojonegoro sebagai salah satu Perangkat Daerah yang dibentuk berdasarkan Peraturan Bupati Bojonegoro Nomor 73 Tahun 2016 tentang Kedudukan, Susunan Organisasi, Uraian Tugas dan Fungsi Serta Tata Kerja Badan Perencanaan Pembangunan Daerah Kabupaten Bojonegoro. Bappeda Kabupaten Bojonegoro mempunyai tugas membantu Bupati melaksanakan fungsi penunjang urusan Pemerintahan yang menjadi kewenangan Daerah di bidang perencanaan, penelitian dan pengembangan. Fungsi tersebut antara lain adalah:

a. Penyusunan kebijakan teknis di bidang perencanaan dan di bidang penelitian dan pengembangan.

b. Pelaksanaan tugas dukungan teknis di bidang perencanaan dan di bidang penelitian dan pengembangan.

c. Pemantauan, evaluasi, dan pelaporan pelaksanaan tugas dukungan teknis di bidang perencanaan dan di bidang penelitian dan pengembangan.

d. Pembinaan teknis penyelenggaraan fungsi-fungsi penunjang urusan Pemerintahan Daerah di bidang perencanaan dan di bidang penelitian dan pengembangan.

e. Pelaksanaan administrasi badan di bidang perencanaan dan di bidang penelitian dan pengembangan.

f. Pelaksanaan tugas lain yang diberikan oleh Bupati sesuai dengan tugas dan fungsinya.

Kepuasan kerja merupakan sikap secara umum yang lebih diwarnai oleh perasaan terhadap situasi dan lingkungan kerja serta merupakan pencerminan dari kepuasan seorang pegawai terhadap kondisi yang berkaitan dengan pelaksanaan pekerjaan. Kepuasan kerja juga mempunyai hubungan dengan umur, semakin tua umur pegawai, mereka cenderung lebih terpuaskan dengan pekerjaan-pekerjaan mereka. Pengharapan-pengharapan yang lebih rendah dan penyesuaian yang lebih baik terhadap situasi kerja karena mereka lebih berpengalaman, menjadi alasan yang melatar belakangi kepuasan kerja mereka. Pegawai akan merasa puas atau tidak puas tergantung pada perbedaan antara apa yang diharapkan dari masing-masing pegawai tersebut. Apabila yang didapat pegawai lebih rendah dari pada yang diharapkan akan menyebabkan pegawai tidak puas, begitu juga sebaliknya.

Komunikasi merupakan proses dua arah yang memberikan kesempatan kepada orang yang berkomunikasi untuk merespon dan juga menyampaikan pesan-pesan. Hal ini dilihat dari terjadinya hubungan kerjasama antar karyawan dan karyawan dengan pimpinan (Denny, 2017). Komunikasi merupakan proses yang tidak dapat dihindari 
oleh setiap anggota organisasi. Komunikasi penting bagi suatu organisasi karena komunikasi merupakan alat utama bagi anggota organisasi untuk dapat bekerja sama dalam melakukan aktivitas manajemen, yaitu untuk mencapai tujuan organisasi yang telah ditetapkan sebelumnya.

Komunikasi menjadi hal yang sangat penting untuk diperhatikan terutama kaitannya dengan kepuasan kerja. Karena komunikasi mempunyai hubungan yang positif dengan kepuasan kerja seseorang, menurut Titik (2015) dalam penelitiannya yang menyatakan bahwa komunikasi berpengaruh signifikan dan positif terhadap kepuasan kerja karyawan. Akan tetapi berbeda dengan penelitian yang dilakukan oleh Pratiwi dan Sariyathi (2015) yang menyatakan bahwa komunikasi, tidak berpengaruh signifikan terhadap kepuasan kerja.

Jika kepuasan kerja pegawai sudah tercapai, maka dengan mudah tujuan-tujuan Bappeda Kabupaten Bojonegoro dapat terwujud. Oleh karena itu peneliti tertarik untuk melakukan penelitian dengan judul "Kepuasan kerja pegawai Bappeda Kabupaten Bojonegoro Ditinjau dari Aspek Komunikasi, Motivasi dan Lingkungan kerja"

\section{Rumusan Masalah}

Berdasarkan latar belakang tersebut, maka rumusan dalam penelitian ini adalah sebagai berikut:

1. Bagaimana kondisi komunikasi, motivasi dan lingkungan kerja serta kepuasan kerja pegawai di Bappeda Kabupaten Bojonegoro?

2. Apakah komunikasi, motivasi dan lingkungan kerja secara Simultan berpengaruh signifikan terhadap kepuasan kerja pegawai di Bappeda Kabupaten Bojonegoro?

3. Apakah komunikasi, motivasi dan lingkungan kerja secara Parsial berpengaruh signifikan terhadap kepuasan kerja pegawai di Bappeda Kabupaten Bojonegoro?

\section{Tujuan penelitian}

adalah untuk:

Berdasarkan pada perumusan masalah tersebut, maka tujuan penelitian ini

1. Mendeskripsikan komunikasi, motivasi dan lingkungan kerja serta kepuasan kerja pegawai di Bappeda Kabupaten Bojonegoro.

2. Mengetahui dan menganalisis pengaruh komunikasi, motivasi dan lingkungan kerja secara simultan terhadap kepuasan kerja pegawai di Bappeda Kabupaten Bojonegoro.

3. Mengetahui dan menganalisis pengaruh komunikasi, motivasi dan lingkungan kerja secara parsial terhadap kepuasan kerja pegawai di Bappeda Kabupaten Bojonegoro.

\section{Manfaat Penelitian}

Manfaat penelitian ini terbagai menjadi manfaat secara teoritis dan praktis, yang dapat dijelaskan sebagai berikut :

1. Manfaat Teoritis

Manfaat penelitian ini secara teoritis diharapkan dapat:

a. Menambah pengetahuan pembaca pada umumnya dan peneliti pada khususnya tentang peningkatan kepuasan kerja pegawai melalui komunikasi, motivasi dan lingkungan kerja. 
b. Memberikan sumbangan bagi khasanah keilmuan terhadap lembaga pendidikan khususnya di bidang Manajemen SDM berkaitan dengan peningkatan kepuasan kerja.

\section{Manfaat Praktis}

Manfaat penelitian ini secara praktis dapat dijelaskan sebagai berikut:

a. Bagi peneliti, penelitian ini dapat menambah pengetahuan dan wawasan mengenai kepuasan kerja pegawai d Bappeda Kabupaten Bojonegoro.

b. Bagi pimpinan Bappeda Kabupaten Bojonegoro, penelitian ini dapat memberikan masukan secara tertulis maupun sebagai referensi bilamana memerlukan bentuk-bentuk mengenai peningkatan kepuasan kerja pegawai melalui melalui komunikasi, motivasi dan lingkungan kerja yang baik dan mungkin bisa dilaksanakan.

c. Bagi pegawai, penelitian ini dapat memberikan pandangan tentang cara meningkatkan kepuasan kerja yang baik dan benar melalui komunikasi, motivasi dan lingkungan kerja di Bappeda Kabupaten Bojonegoro.

d. Bagi perguruan tinggi, penelitian ini memberikan kontribusi untuk menambah referensi perpustakaan sehingga dapat digunakan sebagai dasar penelitian yang dilakukan selanjutnya.

\section{KAJIAN PUSTAKA \\ Kepuasan Kerja}

Menurut Wexley dan Yulk dalam Gibson (2010) kepuasan kerja adalah sebagai perasaan seseorang terhadap pekerjaannya. Dan kepuasan kerja merupakan suatu persepsi terhadap kondisi yang seharusnya ada dan persepsi terhadap kondisi-kondisi kerja aktual di lingkungan kerja. Sedangkan menurut Handoko (2011) kepuasan kerja adalah keadaan emosional yang menyenangkan atau tidak menyenangkan sejauh karyawan memandang pekerjaan mereka.

Kepuasan kerja merupakan tingkatan diamana individu merasa bahwa mereka dihargai seimbang melalui berbagai aspek situasi pekerjaannya dan organisasi dimana mereka bergantung. Seseorang dengan tingkat kepuasan kerja yang tinggi akan mempertahankan sikap positif terhadap pekerjaannya, sementara seseorang yang tidak puas dengan pekerjaannya akan mempertahankan sikap negatif mengenai pekerjaannya. Kepuasan kerja berhubungan dengan kognitif individu, afektif dan reaksi evaluasi terhadap pekerjaannya (Baron dan Greenberg) dalam Handoko (2011).

\section{Komunikasi}

Komunikasi adalah bentuk interaksi manusia yang saling pengaruh mempengaruhi satu dengan yang lainnya, sengaja atau tidak sengaja. Tidak terbatas pada bentuk komunikasi menggunakan bahasa verbal, tetapi juga dalam hal ekspresi muka, lukisan, seni, dan teknologi. (Shanon \& Weaver, 2010) Menurut Carl I. Hovland "Communication is the process by which individual (the communicator) transmits stimuly (usually verbal symbols) to modify the behavior of other individuals." Komunikasi adalah proses dimana seorang individu (komunikator) mengubah rangsangan (biasanya simbol verbal) untuk mengubah perilaku orang lain. 
Komunikasi secara mudah diartikan sebagai proses transfer pesan melalui sarana atau media komunikasi kepada komunikan yang dituju. Komunikasi adalah proses mengubah perilaku orang lain. (Effendi, 2010) Berdasarkan definisi tersebut, peneliti memahami bahwa komunikasi dapat mengubah sikap, pendapat, dan perilaku seseorang. Pada kesimpulannya, komunikasi adalah sebuah proses penyampaian pesan yang disampaikan dari komunikator kepada komunikan melalui media tertentu untuk mengasilkan efek atau tujuan dengan harapan mendapatkan feedback atau umpan balik.

\section{Motivasi}

Istilah motivasi (motivation) berasal dari bahasa latin, yakni movere, yang berarti "menggerakan" (to move). Menurut Fillmore H. Stanford dalam Mangkunegara, (2009:93) motivasi sebagai berikut: "Motivasi adalah kondisi yang menggerakan pegawai agar mampu mencapai tujuan dari motif". Pola awal motivasi menggerakan seseorang untuk mengetahui masalah pokok yang terkandung dalam motivasi sehinga mereka mengetahui apa yang mendorong seseorang itu mau bekerja adalah awal dan motif. Veithzal Rivai (2011) menyatakan bahwa motivasi kerja adalah serangkaian sikap dan nilai-nilai yang mempengaruhi individu untuk mencapai hal yang spesifik sesuai dengan tujuan individu". Menurut Robbins (2008) motivasi adalah suatu usaha pendorong yang menyebabkan seseorang melakukan sesuatu. Penelitian ini merujuk kepada definisi dari Robbins (2008), bahwa motivasi adalah suatu usaha pendorong yang menyebabkan seseorang melakukan sesuatu.

\section{Lingkungan Kerja}

Lingkungan kerja yang dapat mengganggu kenyamanan dan kepuasan karyawan dalam bekerja sehingga sering menimbulkan stress adalah kebisingan karena suara yang terlalu keras. Dari hasil penelitian menunjukkan kebisingan dapat meningkatkan terjadinya kecelakaan kerja, karena konsentrasi karyawan terganggu menimbulkan sakit kepala, kelelahan, menjadi mudah marah dan sebagainya. Ventilasi udara yang kurang sehingga ruangan menjadi panas dan pengap, penerangan baik dari sinar matahari maupun karena penggunaan lampu yang kurang terang juga dapat mengakibatkan gangguan penglihatan, sakit kepala dan kelelahan. Selain faktor tersebut faktor kebersihan lingkungan kerja juga dapat menjadi sumber stress. Tempat kerja yang bersih, tidak berbau, tidak banyak asap dan tertata rapi dpat menimbulkan rasa nyaman, sehingga dapat membantu konsentrasi dalam bekerja.

Lingkungan kerja adalah termasuk variabel sumber daya didalam lingkup organisasi. (Gibson, 2010), selain manusia sebagai kondisi yang dapat mendukung perilaku kerja. Dikatakan mendukung karena tanpa lingkungan kerja yang memadai, pekerjaan akan menjadi lambat, terganggu, bahkan dapat terhenti. Dengan demikian lingkungan kerja ini tidak dapat diabaikan karena aktifitas organisasi akan berhasil guna dengan memakai metode atau cara, pemanfaatan sarana dan alat-alat. (Suwarto, 2010).

Pendapat Suma'mur (2010), lingkungan kerja dapat dibagi menjadi lingkungan fisik (ruangan, penerangan, temperatur, peralatan) ; lingkungan kimia (gas, uap, debu) ; lingkungan fisiologis (konstruksi, isi kantor, cara kerja) dan lingkungan sosial. Sedangkan menurut Indriyo Gitosudarmo (2012) menyatakan lingkungan kerja terdiri 
dari lingkungan fisik dan lingkungan organisasi yang menjadikan iklim kerja positif. Pendapat lain dari Kaho dalam Gitosudarmo (2012) yang membahas persiapan otonomi daerah mengatakan bahwa untuk dapat melaksanakan tugas otonomi dengan baik perlu diperhatikan aspek ketersediaan sumber daya non manusia (kendaraan, gedung, fisik, peralatan, material dan lain-lain). Dan Sutermeister dalam Sedarmayanti (2014) juga mengatakan lingkungan kerja sebagai phisical condition yang meliputi lighting, temperature. ventilation, rest period dan safety.

\section{METODE PENELITIAN}

\section{Jenis dan Pendekatan Penelitian}

Dalam proses penelitian membutuhkan waktu yang lama untuk memahami permasalahan yang dibahas untuk berkembang menjadi pembahasan yang teoritis dan konseptual. Salah satu solusi penyelesaian permasalahannya adalah dengan memilih metode yang cocok sesuai jenis penelitian. Jenis penelitian ini adalah penelitian eksplanatory. Penelitian eksplanatori (explanatory research) adalah penelitian yang bertujuan untuk menerangkan pengaruh satu atau beberapa variabel bebas terhadap variabel terikat (Silalahi, 2010:59).

Pendekatan penelitian yang dilakukan dalam penelitian ini adalah pendekatan kuantitatif. Pendekatan kuantitatif sering disebut juga metode tradisional karena sudah lama dipergunakan dalam penelitian-penelitian pada umumnya. Filsafat yang mendasari pendekatan ini adalah positivisme. Karena telah memenuhi kaidah-kaidah ilmiah seperti konkrit, obyektif, terukur, rasional dan sistematis. Adapun data penelitian berupa jawaban pertanyaan pada kuesioner yang ditransformasikan ke dalam bentuk angka-angka dan dianalisis menggunakan alat statistik. Oleh sebab itu, pendekatan yang dipergunakan dalam penelitian ini adalah pendekatan kuantitatif.

\section{Lokasi Penelitian}

Penelitian ini dilaksanakan di Badan Perencanaan Pembangunan Daerah (Bappeda) di Kabupaten Bojonegoro. Adapun kantor Badan Perencanaan Pembangunan Daerah di Kabupaten Bojonegoro beralamatkan di Jalan P. Mas Tumapel 01 Gedung Pemkab Lt. 4 Bojonegoro 62111.

\section{Populasi, Sampel dan Teknik Pengambilan Sampel}

Populasi adalah wilayah generalisasi yang terdiri atas obyek/subyek yang mempunyai kualitas dan karakteristik tertentu yang diterapkan oleh peneliti untuk dipelajari dan kemudian ditarik kesimpulannya (Sugiyono, 2012). Populasi dalam penelitian ini adalah Pegawai Badan Perencanaan Pembangunan Daerah Kabupaten Bojonegoro sebanyak 39 orang.

Sampel adalah bagian dari jumlah dan karakteristik yang dimiliki oleh populasi (Sugiyono, 2012). Jumlah sampel yang digunakan dalam penelitian ini sebanyak 38 orang yang merupakan pegawai Badan Perencanaan Pembangunan Daerah Kabupaten Bojonegoro.

Teknik pengambilan sampel yang digunakan dalam penelitian ini diambil secara total atau menggunakan metode sensus sampling sehingga keseluruhan populasi 
dijadikan sampel penelitian. Metode sensus sampling digunakan mengingat jumlah populasinya sedikit.

\section{Teknik Analisis Data}

Teknik analisis data menggunakan teknik uji statistik melalui alat bantu program SPSS. Dengan teknik analisis demikian ini, maka pembuktian hipotesis dapat dilakukan. Untuk mengetahui pengaruh antar variabel digunakan analisis dengan teknik Regresi Linier Berganda.

\section{HASIL PENELITIAN DAN PEMBAHASAN \\ Hasil Penelitian}

Statistik deskriptif digunakan untuk menggambarkan suatu data secara statistik. Statistik deskriptif dalam penelitian ini merujuk pada nilai rata-rata (mean) dari seluruh variabel dalam penelitian ini yaitu kepuasan kerja $(\mathrm{Y})$, komunikasi $\left(\mathrm{X}_{1}\right)$, motivasi $\left(\mathrm{X}_{2}\right)$ dan lingkungan kerja $\left(\mathrm{X}_{3}\right)$ sebagaimana ditunjukkan pada tabel berikut:

Tabel 1. Descriptive Statistics

\begin{tabular}{|l|l|l|l|l|l|}
\hline & N & Minimum & Maximum & Mean & $\begin{array}{l}\text { Std. } \\
\text { Deviation }\end{array}$ \\
\hline Komunikasi & 38 & 2.80 & 5.00 & 3.7105 & .60036 \\
\hline Motivasi & 38 & 2.60 & 5.00 & 3.5053 & .52347 \\
\hline Lingkungan kerja & 38 & 2.88 & 5.00 & 3.8966 & .57944 \\
\hline Kepuasan kerja & 38 & 2.20 & 5.00 & 3.5526 & .59445 \\
\hline Valid N (listwise) & 38 & & & & \\
\hline
\end{tabular}

Sumber : Hasil Penelitian, diolah (2019)

Dari data tersebut dapat diketahui variabel komunikasi memiliki nilai mean sebesar 3.7105, variabel motivasi memiliki nilai mean sebesar 3.5053, variabel lingkungan kerja memiliki nilai mean sebesar 3.8966 dan variabel kepuasan kerja memiliki nilai mean sebesar 3.5526. Mengenai skala penilaian nilai mean pada masingmasing variabel, dapat dilihat pada tabel berikut:

\section{Tabel 2. Kategori Variabel Penelitian}

\begin{tabular}{|l|l|}
\hline $0,00-1,80$ & Tidak baik \\
\hline $1,81-2,60$ & Kurang baik \\
\hline $2,61-3,40$ & Cukup baik \\
\hline $3,41-4,20$ & Baik \\
\hline $4,21-5,00$ & Sangat baik \\
\hline
\end{tabular}

Sumber : Hasil Penelitian, diolah (2019)

Dari tabel tersebut dapat diketahui bahwa variabel komunikasi dalam kategori baik, variabel motivasi dalam kategori baik, lingkungan kerja dalam kondisi baik dan variabel kepuasan kerja juga dalam kategori baik.

Selanjutnya untuk menguji hipotesis yang menyatakan bahwa komunikasi, motivasi dan lingkungan kerja secara simultan mempunyai pengaruh yang signifikan terhadap kepuasan kerja digunakan analisis dengan uji F. Hal ini dapat dilihat pada tabel berikut : 
Tabel 3. Hasil Analisis of Varians (ANOVA)

\begin{tabular}{|l|l|l|l|l|l|}
\hline Model & $\begin{array}{l}\text { Sum of } \\
\text { Square }\end{array}$ & df & $\begin{array}{l}\text { Mean } \\
\text { Square }\end{array}$ & F & Sig \\
\hline Regression & 9.302 & 3 & 3.101 & 27.941 & $.000^{\mathrm{a}}$ \\
$\quad$ Residual & 3.773 & 34 & .111 & & \\
Total & 13.075 & 37 & & & \\
\hline
\end{tabular}

Sumber : Hasil Penelitian, diolah (2019)

Berdasarkan hasil analisis data diperoleh nilai uji $\mathrm{F}$ hitung sebesar 27.941 dengan tingkat signifikansi sebesar 0.000 artinya bahwa komunikasi, motivasi dan lingkungan kerja secara simultan berpengaruh signifikan terhadap kepuasan kerja. Dengan demikian dapat dikatakan bahwa hipotesis yang menyatakan bahwa komunikasi, motivasi dan lingkungan kerja secara simultan berpengaruh secara signifikan terhadap kepuasan kerja pegawai di Bappeda Kabupaten Bojonegoro diterima.

Untuk mengetahui seberapa besar kepuasan kerja pegawai di Bappeda Kabupaten Bojonegoro dapat dijelaskan oleh komunikasi, motivasi dan lingkungan kerja dan dijelaskan pada tabel berikut:

Tabel 4. Model Summary

\begin{tabular}{|l|l|l|l|l|}
\hline Model & $\mathbf{R}$ & $\begin{array}{l}\mathbf{R} \\
\text { Square }\end{array}$ & $\begin{array}{l}\text { Adjusted R } \\
\text { Square }\end{array}$ & $\begin{array}{l}\text { Std Error of } \\
\text { the estimate }\end{array}$ \\
\hline 1 & $.843^{\mathrm{a}}$ & .711 & .686 & .33312 \\
\hline
\end{tabular}

Sumber : Hasil Penelitian, diolah (2019)

Hasil analisis data menunjukkan bahwa koefisien determinasi adalah sebesar 0.711 atau sebesar $71.1 \%$ Artinya bahwa sebesar $71.1 \%$ kepuasan kerja dapat dijelaskan oleh komunikasi, motivasi dan lingkungan kerja, sedangkan sisanya sebesar 28.9\% dijelaskan oleh variabel lain diluar peneltian ini.

Selanjutnya untuk menguji hipotesis yang telah diajukan pada penelitian ini digunakan analisis statistik inferensial. Hasil analisis data dengan menggunakan SPSS (Statistical Program for Social Science) diperoleh sebagai berikut :

Tabel 5. Hasil Analisis Regresi

\begin{tabular}{|c|c|c|c|c|c|c|}
\hline \multirow{2}{*}{\multicolumn{2}{|c|}{ Model }} & \multicolumn{2}{|c|}{$\begin{array}{l}\text { Unstandardized } \\
\text { Coefficients }\end{array}$} & \multirow{2}{*}{$\begin{array}{l}\text { Standardized } \\
\text { Coefficients } \\
\text { Beta }\end{array}$} & \multirow[t]{2}{*}{$\mathrm{t}$} & \multirow[t]{2}{*}{ Sig. } \\
\hline & & B & Std. Error & & & \\
\hline \multirow[t]{4}{*}{1} & (Constant) & .325 & .433 & & .750 & .458 \\
\hline & Komunikasi $\left(\mathrm{X}_{1}\right)$ & .022 & .139 & .022 & .159 & .874 \\
\hline & Motivasi $\left(\mathrm{X}_{2}\right)$ & .601 & .165 & .530 & 3.636 & .001 \\
\hline & Lingkungan kerja $\left(\mathrm{X}_{3}\right)$ & .433 & .110 & .422 & 3.929 & .000 \\
\hline
\end{tabular}

Sumber : Hasil Penelitian, diolah (2019)

Berdasarkan hasil analisis data sebagaimana pada tabel tersebut, dapat dibuat persamaan regresi sebagai berikut:

$$
\mathrm{Y}=0.325+0.022\left(\mathrm{X}_{1}\right)+0.601\left(\mathrm{X}_{2}\right)+0.433\left(\mathrm{X}_{3}\right)
$$

Persamaan diatas menunjukkan bahwa ada pengaruh yang positif dari komunikasi, motivasi dan lingkungan kerja. Nilai konstanta sebesar 0.325 mengandung makna bahwa apabila tidak ada komunikasi, motivasi dan lingkungan kerja serta 
variabel lain, maka tingkat konstanta sebesar 0.325 satuan. Nilai 0.022 menunjukkan bahwa apabila ada kenaikan pada komunikasi sebesar satu satuan maka akan meningkatkan kepuasan kerja pegawai di Bappeda Kabupaten Bojonegoro sebesar Nilai 0.022 satuan. Nilai 0.601 menunjukkan bahwa apabila ada peningkatan dalam motivasi sebesar satu satuan akan meningkatkan kepuasan kerja pegawai di Bappeda Kabupaten Bojonegoro sebesar Nilai 0.601 satuan. Nilai 0.433 menunjukkan bahwa apabila ada peningkatan dalam lingkungan kerja sebesar satu satuan akan meningkatkan kepuasan kerja pegawai di Bappeda Kabupaten Bojonegoro sebesar Nilai 0.433 satuan.

Selanjutnya untuk mengetahui pengaruh komunikasi, motivasi dan lingkungan kerja secara parsial terhadap kepuasan kerja dapat juga dilihat dari tabel dengan penjelasan sebagai berikut:

a. Nilai t hitung untuk komunikasi sebesar 0.159 dengan tingkat signifikansi sebesar 0.874 karena nilai signifikansi 0.874 (lebih besar dari 0,05), maka komunikasi mempunyai pengaruh tidak signifikan terhadap kepuasan kerja.

b. Nilai t hitung untuk motivasi sebesar 3.636 dengan tingkat signifikansi sebesar 0.001 karena nilai signifikansi 0.001 (lebih kecil dari 0,05) maka motivasi mempunyai pengaruh signifikan terhadap kepuasan kerja.

c. Nilai t hitung untuk lingkungan kerja sebesar 3.929 dengan tingkat signifikansi sebesar 0.000 karena nilai signifikansi 0.000 (lebih kecil dari 0,05) maka lingkungan kerja mempunyai pengaruh signifikan positif terhadap kepuasan kerja.

Berdasarkan hasil analisis data maka hipotesis yang menyatakan bahwa komunikasi, motivasi dan lingkungan kerja secara parsial berpengaruh secara signifikan terhadap kepuasan kerja pegawai di Bappeda Kabupaten Bojonegoro ditolak karena komunikasi tidak mempunyai pengaruh yang signifikan terhadap kepuasan kerja.

\section{Pembahasan}

Berdasarkan hasil pengujian deskriptif statistik didapatkan bahwa variabel komunikasi, variabel motivasi, variabel lingkungan kerja dan variabel Kepuasan kerja pegawai Bappeda Kabupaten Bojonegoro dalam kategori baik. Kategori ini mengindikasikan bahwa Bappeda Kabupaten Bojonegoro sudah menunjukkan keberhasilannya dalam memberikan komunikasi kepada para pegawai, disamping itu juga dapat membentuk dengan baik motivasi dan lingkungan kerja pegawai sehingga dapat menciptakan kepuasan kerja.

Berdasarkan hasil analisis data secara simultan dapat dijelaskan bahwa variabel komunikasi, motivasi dan lingkungan kerja berpengaruh signifikan terhadap Kepuasan kerja pegawai Bappeda Kabupaten Bojonegoro, hal tersebut dapat dibuktikan melalui tabel 4.14. Hasil analisis data diperoleh nilai uji $\mathrm{F}$ hitung sebesar 27.941 dengan tingkat signifikansi sebesar 0.000 artinya bahwa komunikasi, motivasi dan lingkungan kerja secara simultan berpengaruh signifikan terhadap kepuasan kerja. Dengan demikian dapat dikatakan bahwa komunikasi, motivasi dan lingkungan kerja secara simultan berpengaruh secara signifikan terhadap kepuasan kerja pegawai di Bappeda Kabupaten Bojonegoro. Maka apabila secara simultan ada perubahan pada komunikasi, motivasi dan lingkungan kerja maka akan berpengaruh secara signifikan pada perubahan 
pencapaian Kepuasan kerja pegawai Bappeda Kabupaten Bojonegoro. Berdasarkan penelitian yang telah dilakukan didapatkan hasil bahwa sebesar 71.1\% Kepuasan kerja pegawai Bappeda Kabupaten Bojonegoro dipengaruhi oleh variabel komunikasi, motivasi dan lingkungan kerja. Sedangkan sisanya 28.9\% Kepuasan kerja pegawai Bappeda Kabupaten Bojonegoro dipengaruhi oleh varibel lain, selain variabel komunikasi, motivasi dan lingkungan kerja pada penelitian ini.

Berdasarkan hasil analisis data, variabel komunikasi secara parsial mempunyai pengaruh yang tidak signifikan terhadap kepuasan kerja pegawai Bappeda Kabupaten Bojonegoro. Hal ini dapat dibuktikan pada tabel 4.16. Nilai t hitung untuk komunikasi sebesar 0.159 dengan tingkat signifikansi sebesar 0.874 karena nilai signifikansi 0.874 (lebih besar dari 0,05). Sehingga apabila ada perubahan pada variabel komunikasi ini tidak akan berpengaruh signifikan pada peningkatan atau penurunan Kepuasan kerja pegawai Bappeda Kabupaten Bojonegoro. Hal ini dapat disebabkan oleh sebagian besar pegawai yang mempersepsikan komunikasi kerja dengan sangat baik, terutama jika dilihat dari segi instruksi kerja yang diberikan oleh atasan kepada bawahan, begitu juga pada penyelesaian terhadap segala informasi yang ada di Bappeda Kabupaten Bojonegoro sudah dapat diselesaikan dengan baik. Hasil penelitian ini tidak mendukung penelitian yang dilakukan oleh Titik (2015) yang menyatakan bahwa komunikasi memiliki pengaruh signifikan terhadap kepuasan kerja.

Berdasarkan hasil analisis data, variabel motivasi secara parsial mempunyai pengaruh yang signifikan terhadap Kepuasan kerja pegawai Bappeda Kabupaten Bojonegoro. Hal ini ditunjukkan pada tabel 4.16. Nilai t hitung untuk motivasi sebesar 3.636 dengan tingkat signifikansi sebesar 0.001 karena nilai signifikansi 0.001 (lebih kecil dari 0,05). Sehingga apabila ada perubahan pada motivasi kerja pegawai, maka akan meningkatkan kepuasan kerja pegawai Bappeda Kabupaten Bojonegoro secara signifikan. Peningkatan motivasi kerja dapat dilakukan dengan perbaikan kebutuhan fisik pegawai, peningkatan rasa aman pegawai, meningkatkan kepedulian sosial pegawai, memberikan penghargaan pada pegawai yang berprestasi dan meningkatkan aktuaisasi diri pegawai Bappeda Kabupaten Bojonegoro. Hasil penelitian ini mendukung pada penelitian yang dilakukan oleh Pratiwi dan Sariyathi (2015) yang menyatakan bahwa motivasi memiliki pengaruh yang signifikan terhadap kepuasaan kerja.

Berdasarkan hasil analisis data juga didapatkan bahwa variabel lingkungan kerja secara parsial mempunyai pengaruh yang signifikan terhadap Kepuasan kerja pegawai Bappeda Kabupaten Bojonegoro, hal ini dapat ditunjukkan pada tabel 4.16. Nilai t hitung untuk lingkungan kerja sebesar 3.929 dengan tingkat signifikansi sebesar 0.000 karena nilai signifikansi 0.000 (lebih kecil dari 0,05). Sehingga apabila ada perubahan pada lingkungan kerja pegawai, maka akan meningkatkan kepuasan kerja pegawai Bappeda Kabupaten Bojonegoro secara signifikan. Peningkatan lingkungan kerja di Bappeda Kabupaten Bojonegoro dapat dilakukan dengan pemberian penerangan ditempat kerja yang cukup, menjaga suhu udara di tempat kerja, mengurangi kebisingan yang disebabkan dari luar maupun dari dalam tempat kerja, medekorasi warna yang dapat membuat pegawai merasa nyaman di tempat kerja, memberikan keleluasaan gerak bagi pegawai, menjaga hubungan baik sesama pegawai maupun dengan pimpinan di Bappeda Kabupaten Bojonegoro. Hasil ini sejalan dengan 
penelitian yang dilakukan oleh Wuwungan (2017) yang menyatakan bahwa Lingkungan Kerja secara Parsial berpengaruh positif dan signifikan terhadap Kepuasan Kerja Karyawan.

\section{KESIMPULAN DAN SARAN Kesimpulan}

Berdasarkan hasil analisa dan pembahasan yang sudah dilakukan, maka dapat disimpulkan sebagai berikut:

1. Kondisi komunikasi, motivasi, lingkungan kerja dan Kepuasan kerja di Bappeda Kabupaten Bojonegoro semuanya dalam kategori baik.

2. Secara simultan komunikasi, motivasi dan lingkungan kerja mempunyai pengaruh yang signifikan terhadap Kepuasan kerja pegawai Bappeda Kabupaten Bojonegoro.

3. Motivasi dan lingkungan kerja secara parsial mempunyai pengaruh yang signifikan terhadap Kepuasan kerja pegawai Bappeda Kabupaten Bojonegoro. Sedangkan komunikasi tidak mempunyai pengaruh yang signifikan terhadap kepuasan kerja pegawai.

\section{Saran}

Berdasarkan hasil penelitian dan kesimpulan, penulis dapat mengajukan beberapa saran sebagai berikut :

1. Meskipun variabel komunikasi, motivasi, lingkungan kerja dan Kepuasan kerja pegawai Bappeda Kabupaten Bojonegoro sudah dalam kategori baik, akan tetapi masih diperlukan upaya yang lebih keras lagi melalui langkah-langkah yang lebih kreatif dan inovatif sehingga mampu meningkatkan kondisi komunikasi, motivasi, lingkungan kerja dan kepuasan kerja.

2. Lingkungan kerja mempunyai pengaruh yang paling dominan terhadap Kepuasan kerja. Sehingga apabila ingin meningkatkan Kepuasan kerja harus lebih diprioritaskan pada meningkatkan lingkungan kerja. Peningkatan dapat dilakukan dengan menjaga suhu udara di tempat kerja, mendekorasi warna yang dapat membuat pegawai merasa nyaman di tempat kerja, memberian penerangan ditempat kerja yang cukup dan lain sebagainya.

\section{DAFTAR PUSTAKA}

Alma, Buchori. 2010. Psikologi Komunikasi. Bandung : Psikologi Komunikasi.

Arwati, Dini, dan Novita Hadiati. 2013. Pengaruh Pertumbuhan Ekonomi, Pendapatan Asli Daerah dan Dana Alokasi Umum Terhadap Pengalokasian Anggaran Belanja Modal pada Pemerintah Daerah Kabupaten/Kota di Propinsi Jawa Barat. Seminar Nasional Teknologi Informasi dan Komunikasi Terapan 2013 (SEMANTIK 2013). 498-507

As'ad, M. 2011. Psikologi Industri. Yogyakarta: Yogyakarta Lyberty.

Denny, Silvani. 2017. Pengaruh Komunikasi, Motivasi dan Kerjasama Tim terhadap Peningkatan Kinerja Karyawan. Jurnal Manajemen \& Kewirausahaan Vol.5 No.

12017 : Universitas Merdeka Malang

Fatmala, Rika. 2017. Pengaruh Lingkungan Kerja, Komunikasi Internal, dan Kerjasama Tim terhadap Kinerja Pegawai di Dinas Kehutanan Provinsi 
Kepulauan Bangka Belitung. Jurnal Ekonomi Vol.3 No. 22017 : Universitas Bangka Belitung

Ghozali, Imam. 2012. Aplikasi Analisis Multivariate dengan Program IBM SPSS. Semarang: Badan Penerbit - Universitas Diponegoro

Gibson, M. 2010. Manajemen Sumber Daya Manusia. Cetakan kedua. Jakarta: Erlangga.

Gitosudarmo, Indriyo. 2012. Manajemen. Edisi kedua, cetakan kedua. Penerbit : BPFEYogyakarta

Handoko, T. Hani. 2011. Manajemen Personalia dan Sumber Daya Manusia. Liberty: Yogyakarta

Harrianto R. 2010. Buku Ajar Kesehatan Kerja. Jakarta: Buku Kedokteran EGC.

Hasibuan, Malayu S.P. 2011. Manajemen: Dasar, Pengertian dan Masalah. Jakarta: PT Aksara.

Husein Umar, 2010. Metode Penelitian. Jakarta : Salemba Empat

ILO. 2013. Health and Safety in Work Place for Productivity. Geneva: International Labour Office.

Mangkunegara, A.A. Anwar Prabu, 2009. Manajemen Sumberdaya Manusia. Remaja Rosdakarya. Bandung.

Mardalis. 2008. Metode Penelitian Suatu Pendekatan Proposal. Jakarta: Bumi Aksara.

Marji, Maulana. 2012. Pengaruh Lingkungan Kerja terhadap Kinerja Karyawan. Jurnal Administrasi Bisnis (JAB) Vol. 44 No. 1 Maret 2012 : Universitas Brawijaya Malang

Maslow, Abraham ,H. 2010, Motivation and Personality. Jakarta: Rajawali.

Novita, Linda. 2013. Analisis Pengaruh Kualitas Kehidupan Kerja dan Kepuasan Kerja Terhadap Kinerja Karyawan Bagian Fillet Dengan Metode Partial Least Square (PLS) (Studi Kasus Di PT X). Management Analysis Journal 5 (4) : Universita Negeri Semarang

Peraturan Bupati Bojonegoro Nomor 73 Tahun 2016 tentang Kedudukan, Susunan, Organisasi, Uraian Tugas dan Fungsi Serta Tata Kerja Badan Perencanaan Pembangunan Daerah Kabupaten Bojonegoro.

Pratiwi, I Gusti Agung Ayu Inten dan Sariyathi Ni Ketut. 2015. Pengaruh Komunikasi, Motivasi, Dan Penegakan Disiplin Terhadap Kepuasan Kerja Pada Pegawai Dinas Pendapatan Di Kabupaten Tabanan. E-Jurnal Manajemen Unud, Vol. 4, No. 7, 2015

Rivai, Veithzal. 2011, Manajemen Sumber Daya Manusia untuk Perusahaan: dari Teori ke Praktik, Jakarta: Raja Grafindo Persada

Robbins, S. 2008. Perilaku Organisasi, Jilid I dan II, alih Bahasa :Hadyana Pujaatmaja. Jakarta: Prenhallindo.

Sedarmayanti. 2014. Sumber Daya Manusia dan Produktivitas Kerja. Jakarta: Mandar Maju.

Shannon, Calude and Weaver. 2010. The Mathematical Theory of Communication.

Siagian, Sondang., P. 2011. Manajemen Sumber Daya Manusia (Edisi Pertama). Jakarta: Binapura Aksara.

Sugiyono. 2012. Metode Penelitian Kuantitatif, Kualitatif dan R\&D. Bandung: Afabeta. 
Suma'mur. 2010. Hiegiene Perusahaan dan Keselamatan Kerja. Jakarta : CV Sagung Seto.

Suwarto. 2010. Perilaku Keorganisasian. Yogyakarta: Universitas Atma Jaya

Winarningsih, Titik. 2015. Pengaruh Lingkungan Kerja, Kepemimpinan, Komunikasi Terhadap Kepuasan Kerja Karyawan KPRI Migas Cepu. Jurnal Ilmu dan Riset Manajemen, Volume 4, Nomor 7, Juli 2015.

Wuwungan, Yulia, Roma, Taroreh, Rita N., dan Uhing Yantje. 2017. Pengaruh Lingkungan Kerja dan Motivasi Kerja Terhadap Kepuasan Kerja Karyawan CINEMAXX Lippo Plaza Manado. Jurnal EMBA, Vol.5 No.2 Juni 2017. ISSN 2303-1174 : Universitas Samratulangi 